\title{
Effects Of Product-Based Technology Professional Development Model On P-8 Teachers
}

\author{
Maduakolam Ireh, (E-mail: irehm@wssu.edu), Winston Salem State University
}

\section{INTRODUCTION}

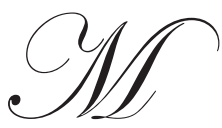

any policy reports have emphasized the importance of linking technology-focused professional development to teachers' immediate needs and interests, rather than simply delivering technical training on software independent of the curricular or instructional needs of participants (Office of Technology Assessment, 2000; The CEO Forum on Education and Technology, 1999; U.S. Department of Education, 1999). Riel and Becker (2000) found that teachers who regularly seek out professional development opportunities or who lead such programs for their colleagues are also more likely than their colleagues to be experienced users of educational technology, suggesting that these are teachers who have found relevant connections between what educational technology has to offer and their own agendas for professional growth.

Effective professional development programs for P-8 teachers include features such as organizing teacherlearners into learning communities, providing sustained blocks of time for training and follow-up support, and aligning teachers' knowledge of content, instructional strategies, and assessment practices (Kanaya, Light \& Culp, 2005; National Commission on Teaching and America's Future, 2003; National Staff Development Council, 2001). The educational technology community has built on this consensus, articulating specific qualities that are important to creating professional development that moves beyond providing teachers with technical skills, and instead helps them to integrate technology into their curriculum and into their students' day-to-day classroom activity (Anderson \& Becker, 2001; Office of Technology Assessment, 2000).

Technology professional development programs become successful when they focus on the teacher's stage of use, inform and change teacher behavior, and are field-based (Bailey and Powell, 1998). A teacher who is afraid of technology or a beginning user would be lost in a professional development for power users. Mandinach (1992) described four stages of technology use: survival, mastery, impact and innovation.

- $\quad$ Survival: A teacher in the survival stage struggles against technology; is assailed by problems (everything that can go wrong will); doesn't change the status quo in the classroom; uses technology only for directed instruction; has management problems planning how 30 students will access few computers; has unrealistic expectations, believing that technology use by itself will result in higher academic performance.

- $\quad$ Mastery: A teacher in the mastery stage has increased tolerance to hardware and software problems; begins to use new forms of interaction with students and classroom practices; has increased technical competence and can troubleshoot simple problems.

- Impact: A teacher in the impact stage regularly incorporates new working relationships and class room structures; balances instruction and construction; is rarely threatened by technology; regularly creates technology enhanced instructional units.

- Innovation: A teacher in the innovation stage: modifies his or her classroom environment to take full advantage of technology enhanced curriculum and learning activities.

Teachers must move beyond the "basement and first-floor" technologies with which they are most familiar and into the "upper levels" that incorporate advanced and multifaceted information technologies. Teachers themselves must become competent in the use and integration of existing and emerging technologies into instruction to significantly improve teaching and learning. It is only by being competent users, adapters, and integrators could they, 
in turn, become role models to their students (Bielefeldt, 2000; Milken Exchange on Education Technology, 1998; National Center for Education Statistics, 2000; NCATE, 2003). This paper discusses the effects of a successful product-based professional development model used to train teachers to use and integrate technology in P-8 classrooms in ways that improved learning for learners, especially ESL students in economically disadvantaged, low performing, and high need schools.

\section{THE PRODUCT-BASED MODEL}

The product-based professional development model (Ireh \& Bell, 2002) is similar to job-embedded learning or field-based professional development model (Loucks-Horsley, Hewson, Love \& Stiles, 1997). The model emphasizes ongoing, outcomes-based professional development that fosters continuous improvement (Flowers, Mertens \& Mulhall, 2002). It is built on the premise that faculty professional development should have specific outcomes tied to appropriate context (Flowers et al., 2002; Guskey, 2000). The model was chosen based on previous successes recorded when it was first used to provide technology professional development for teacher education faculty members at a southeastern United States university over a period of three years (Ireh \& Bell, 2002, 2004) through a PT3 grant from the US Department of Education. The model is used in a state-funded grant project- NC Quest - to provide professional development to 18 P-8 teachers from two school systems in the Piedmont Triad of area North Carolina. It is part of North Carolina's Title II-A, "Improving Teacher Quality State Grant designed to help fulfill the mission of the federal "No Child Left Behind" act.

The project, which started last summer 2005 and runs until summer 2006 is housed at Winston-Salem State University (WSSU) and involves 18 teachers of primary/elementary ESL students in economically disadvantaged, low performing, and high need schools. Two of the elementary schools were chosen from the Winston-Salem Forsyth County school system and three primary/elementary schools were chosen from the Thomasville City schools. Under North Carolina's Improving Teacher Quality State Grant, the Thomasville City school system qualified as a low performing school and partner for the project, while the two schools drawn from Winston-Salem City/Forsyth County schools qualified as economically disadvantaged/low performing schools and partners for the project. The project staff consists of six WSSU faculty members and building principals and coordinators from the two school systems. One of the five goals of the project, which will be completed in summer 2006, is to "significantly improve the technology integration skills of teachers in the partnership." Objectives, intended outcomes, and the assessment measures relating to this goal are indicated in Appendix A.

\section{DESIGN OF THE MODEL}

Eighteen (18) P-8 teachers drawn from two school system in the Piedmont Triad of area North Carolina participate in this year-long professional development. It started in summer of 2005 with two weeks intensive ( 8 hours a day) workshop sessions on several topics including effective integration of technology in ESL classrooms. In fall 2005, several day-long workshops held every other Saturday followed. This spring 2006, participants are involved in similar workshops that are held on Saturdays at alternating sites within the two school systems. Topics for the workshops were designed based on the needs analysis conducted by project personnel in spring 2005, prior to starting the project. Some of the technology integration topics covered include (a) creating effective multimedia presentations; creating WebQuests; collecting, analyzing, and communicating classroom/instructional data to various stakeholders; concept mapping, literature circles, integration of United Streaming into ESL curriculum; using Microsoft Movie Maker to create instructional content for use in ESL classrooms, assessing instruction using technology, creating instructional web pages, streaming media for P-8 instruction, etc. These technology professional development activities are shaped by a philosophy emphasizing alignment of instructional activities with standards, problem solving, technology integration, systemic data collection and information management, assessment, presentations, and decision-making in P-8 curriculum.

In designing the content, emphasis was placed on ensuring that participants gained technology integration skills that will help them become more effective in being able to improve the academic performances of their ESL and economically disadvantaged students. As Marzano (2003) noted, this is a necessary condition for school success. It has been found that successful professional development programs for teachers are those that are scientifically- and/or 
evidence-based such as the product-based models (Ireh \& Bell, 2002, 2004; National Center for Education Statistics, 2000; National Council for Accreditation of Teacher Education, 2003). Using a field- or evidence-based professional development models, also known as job-embedded learning (Loucks-Horsley, Hewson, Love, \& Stiles, 1997), the project personnel are able to provide the participants with training in authentic teaching situations and with authentic training experiences and modeling. For example, instead of learning how to use Microsoft Office Suites and deal with issues related to teaching ESL children and diverse cultural identities through hypothetical lessons, teachers participating in the project develop, implement, and evaluate technology-rich, developmentally appropriate lessons and resources using authentic teaching experiences, with modeling and guidance from other experienced and proficient teachers as well as from a team of experienced faculty from WSSU.

Rather than the workshop focusing on knowing how to use a particular product, such as Microsoft FrontPage, the product-based approach focused on "helping participants create instructional resources that are made available to students online. Although the participants eventually used Web authoring software such as Microsoft FrontPage and Dreamweaver for developing their web sites, emphasis was not placed on just learning how to use it, but on developing effective instructional Web site where they could make resources available to students electronically, 24 hours a day. Similarly, teaching a group of teachers how to use a spreadsheet program, just in case they ever want to use it, would gain little acceptance. But, offering them authentic reasons from their daily lives and using typical classroom activities to learn that particular activity (e.g., creating and managing a grade book) produced teachers willing to experiment with spreadsheet programs.

After completing each series of workshops, participants worked on their assigned products individually. Several follow-up and one-on-one workshop sessions were also conducted for those who required further assistance or those who missed parts of earlier workshop sessions. At this stage, several individuals formed peer/support groups for purposes of cooperation and collaboration. For the most part, these collaborations were between teachers from the school system, building or grade level. Guidelines were provided for the end products, and deadlines for submitting them for review and approval were also set. Each completed product was reviewed, using a checklist/rubric, first by a peer chosen by the participant for content and standard requirements and then by the project personnel for overall quality of technology integration. Each finished product was turned in with the checklist/rubric. Participants were required to attend the workshops as well as complete the product(s) in order to receive compensation.

Table 1: Self And Peer Pre And Post-Test Mean Ratings Of Ability To Use Certain Technology Equipment

\begin{tabular}{|c|c|c|c|c|c|c|c|}
\hline \multirow[b]{2}{*}{$\#$} & \multirow[b]{2}{*}{ Equipment } & \multicolumn{3}{|c|}{ Self } & \multicolumn{3}{|c|}{ Peers } \\
\hline & & Pretest & Post-test & Dif. & Pretest & Post-test & Dif. \\
\hline 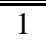 & TV/VCR & 4.0 & 4.2 & 0.2 & 4.8 & 4.6 & -0.2 \\
\hline 2 & LCD Projector & 2.0 & 3.9 & 1.9 & 3.2 & 4.4 & 1.2 \\
\hline 3 & Computer (Desktop or Laptop - Windows platform) & 2.7 & 4.4 & 1.7 & 3.5 & 4.6 & 1.1 \\
\hline 4 & Computer (Desktop or Laptop - Mac platform) & 1.5 & 2.8 & 1.3 & 2.0 & 3.0 & 1.0 \\
\hline 5 & Calculator(s) & 3.5 & 4.2 & 0.7 & 5.0 & 4.7 & -0.3 \\
\hline 6 & Scanner(s) & 2.0 & 3.8 & 1.8 & 2.4 & 3.1 & 0.7 \\
\hline 7 & Digital Camera & 2.2 & 4.5 & 2.3 & 1.8 & 3.4 & 1.6 \\
\hline 8 & Video Camera (Digital or Analog) & 2.5 & 4.6 & 2.1 & 1.5 & 3.0 & 1.5 \\
\hline 9 & PDA (Personal Digital Assistant) & 1.3 & 2.2 & 0.9 & 2.0 & 3.8 & 1.8 \\
\hline 10 & Networked Drives, Devices, Servers, etc & 1.0 & 2.5 & 1.5 & 2.0 & 3.7 & 1.7 \\
\hline 11 & DVD/CD-R/RW, USB Drives & 3.5 & 4.3 & 0.8 & 2.9 & 4.0 & 1.1 \\
\hline 12 & Smart Board & 1.8 & 3.0 & 1.2 & 3.0 & 4.0 & 1.0 \\
\hline 13 & USB Memory Jump Drive & 1.5 & 4.5 & 3.0 & 2.0 & 4.8 & 2.8 \\
\hline
\end{tabular}

NOTE: Differences in Bold (see Dif. column) and higher than 1.5 were deemed moderately significant.

\section{PRELIMINARY FINDINGS}

Baseline data were collected via product rubrics; observations; analysis of completed products and applications in the classroom; structured interviews from all participants, building principals, and P-8 students. In addition, in-house pre and post surveys were conducted by the project personnel determine the teachers' self efficacy 
and technology integration skills. The pre- and post-surveys (Appendix B) consisted of two parts: (a) survey of ability to use and integrate technology equipment and (b) survey of the ability to perform certain instructional technology skills. Ratings on both sections were based on a Likert-type scale of 1 to 5, with 1 - lowest and 5 - highest. Due to the small number of sample, only relevant descriptive finds are presented in Table 1 and Table 2. As shown in the table, posttest ratings were moderately higher (see column labeled "dif." in italics) than pre-ratings for most of the skills/areas. Differences greater than 1.5 were deemed moderate by the project personnel based on preset level of confidence.

Table 2: Pre and Post-test Mean Ratings of Ability to Perform Certain Instructional Technology Skills

\begin{tabular}{|c|c|c|c|c|c|c|c|}
\hline \multirow[b]{2}{*}{ \# } & \multirow[b]{2}{*}{ Instructional Technology Skill } & \multicolumn{3}{|c|}{ Self } & \multicolumn{3}{|c|}{ Peers } \\
\hline & & $\begin{array}{l}\text { Pre- } \\
\text { test }\end{array}$ & $\begin{array}{l}\text { Post } \\
\text {-test }\end{array}$ & Dif. & $\begin{array}{l}\text { Pre- } \\
\text { test }\end{array}$ & $\begin{array}{l}\text { Post } \\
\text {-test }\end{array}$ & Dif. \\
\hline 1 & Word processing to create written documents & 4.2 & 4.6 & 0.4 & 3.5 & 4.3 & 0.8 \\
\hline 2 & Word processing to create news letters, mail merge, templates, flyers, etc & 2.2 & 3.8 & 1.6 & 1.8 & 3.2 & 1.4 \\
\hline 3 & $\begin{array}{l}\text { Desktop publishing software to produce newsletters or other specially } \\
\text { formatted documents }\end{array}$ & 1.8 & 3.7 & 1.9 & 1.4 & 3.4 & 2.0 \\
\hline 4 & $\begin{array}{l}\text { Spreadsheet software to organize, analyze, and report school-related numeric } \\
\text { data }\end{array}$ & 2.1 & 4.0 & 1.9 & 2.4 & 4.2 & 1.8 \\
\hline 5 & Database software to organize and analyze data & 1.3 & 2.9 & 1.6 & 1.1 & 2.4 & 1.3 \\
\hline 6 & Presentations software to create and deliver lessons and for student reports & 2.5 & 4.2 & 1.7 & 2.2 & 4.1 & 1.9 \\
\hline 7 & Drill and practice software to build students' skills & 2.8 & 4.6 & 1.8 & 1.8 & 3.7 & 1.9 \\
\hline 8 & $\begin{array}{l}\text { Simulation software, modeling software, and interactive instructional software } \\
\text { to enhance student learning and analysis of curriculum-related problem } \\
\text { situations }\end{array}$ & 1.2 & 4.1 & 2.9 & 1.3 & 3.4 & 2.1 \\
\hline 9 & $\begin{array}{l}\text { Graphic tools and software to acquire, edit, and incorporate images into } \\
\text { documents }\end{array}$ & 1.6 & 3.7 & 2.1 & 2.0 & 3.1 & 1.1 \\
\hline 10 & $\begin{array}{l}\text { Online instructional tools and simulations to provide curriculum-related } \\
\text { learning experiences }\end{array}$ & 2.2 & 4.4 & 2.2 & 2.4 & 4.6 & 2.2 \\
\hline 11 & Locating appropriate Internet resources for teachers and students & 2.6 & 4.6 & 2.0 & 2.8 & 4.8 & 2.0 \\
\hline 12 & Ability to use the Internet and navigate through pre-organized links & 4.6 & 4.8 & 0.2 & 4.4 & 4.9 & 0.5 \\
\hline 13 & $\begin{array}{l}\text { Use of search strategies to locate useful curricular/instructional resources on } \\
\text { the Internet }\end{array}$ & 2.4 & 4.5 & 2.1 & 3.5 & 4.2 & 0.7 \\
\hline 14 & $\begin{array}{l}\text { Web site (designed with software such FrontPage, Dreamweaver, etc) to } \\
\text { support instruction and communication with students }\end{array}$ & 1.7 & 4.2 & 2.5 & 2.3 & 4.4 & 2.1 \\
\hline 15 & $\begin{array}{l}\text { Charts and graphs for enhancing understanding of information or data being } \\
\text { presented }\end{array}$ & 2.9 & 4.2 & 1.3 & 3.0 & 3.7 & 0.7 \\
\hline 16 & $\begin{array}{l}\text { Knowledge of and adherence to school or district policies, copyright laws, } \\
\text { safety, health, and ethical standards with regard to technology use }\end{array}$ & 3.2 & 4.6 & 1.4 & 2.7 & 4.1 & 1.4 \\
\hline 17 & Select appropriate technology resources for classroom use & 2.7 & 4.0 & 1.3 & 2.6 & 3.8 & 1.2 \\
\hline 18 & Facilitate regular student use of computer technology & 2.9 & 4.5 & 1.6 & 2.5 & 4.1 & 1.6 \\
\hline 19 & Use technology to enhance assessment of students' performances & 1.1 & 4.6 & 3.5 & 1.8 & 3.9 & 2.1 \\
\hline 20 & Use technology to present instruction & 3.1 & 4.7 & 1.6 & 2.8 & 4.6 & 1.8 \\
\hline 21 & Conduct learning activities using computer technology & 2.3 & 4.6 & 2.3 & 2.1 & 4.4 & 2.3 \\
\hline 22 & Integrate technology-based learning experiences into instruction & 2.4 & 4.1 & 1.7 & 2.4 & 3.6 & 1.2 \\
\hline 23 & Use computer technology for problem-solving and critical thinking & 1.4 & 4.5 & 3.1 & 1.2 & 3.8 & 2.6 \\
\hline 24 & Use technology to facilitate individualized or cooperative learning experiences & 1.8 & 4.6 & 2.8 & 1.8 & 4.1 & 2.3 \\
\hline 25 & Create developmentally-appropriate WebQuest activities & 1.6 & 4.1 & 2.5 & 1.2 & 4.6 & 3.4 \\
\hline 26 & Concept mapping using Inspiration or Kidspiration software & 2.5 & 4.6 & 2.1 & 2.8 & 4.8 & 2.0 \\
\hline 27 & Streaming media for use in the classroom & 1.1 & 3.8 & 2.7 & 1.3 & 4.1 & 2.8 \\
\hline 28 & Use computer technology to maintain and analyze student performance & 2.1 & 4.4 & 2.3 & 2.5 & 4.2 & 1.7 \\
\hline
\end{tabular}

NOTE: Differences in Bold (see Dif. column) and higher than 1.5, were deemed moderately significant. 


\section{IMPACT ON PARTICIPANTS}

The workshops enhanced some participants' ability to more clearly articulate curriculum and instruction requirements and relate them to performance objectives. They now employ a wide range of instructional technology skills as part of their own instructional repertoire. They see technology as an effective and powerful tool for enhancing teaching and learning. Few of the specific impacts of NC Quest grant on the participants are evident in what they are able to do as a result of the product-based professional developments; they develop and use multimedia-rich instructional resources in their instruction, especially with their ESL students; integrate WebQuests, problem-solving, concept maps, and visualization into teaching and learning; create instructional materials/resources that are made available to students for use during reading activities such as literature circle; use technology to develop collaborative projects with colleagues within and outside their school building; and know the International Society for Technology in Education (ISTE) (2000) standards for both students and teachers.

There are ample signs of change in participants' efficacy regarding technology usage and integration. One of the participants stated in the project's evaluation report, "What I had been doing was so rudimentary compared to what was required to be done... Another remarked that: I have seen people doing things that they were not doing before. Another participant in one of the elementary schools in the Winston Salem Forsyth County school system described how she is able to use technology integration skills to inspire and challenge her students. She stated that instead of assigning a report to develop a PowerPoint presentation on an aspect of the Civil War (Summary Report type of communication), "I challenged my students to design a monument to commemorate the greatest single event in the Civil War or a 3-D model of the monument into a virtual reality display along with supporting their opinion with facts and cite their sources" (Analyze and Conclude type of communication). Others commented on how and/or why they see technology as a vital tool for instruction this way:

- I use technology to reach my students....technology is one way to not only motivate students to learn, but also to address diverse learning styles.

- I believe that computers and audio-visual technology not only appeal to students, but encourages them to learn.

- $\quad$ Technology lets you incorporate more learning styles, allowing students to display their particular skills....This is a technological world, and these skills are important for my students to learn.

- $\quad$ I use technology to help my students find the lessons more interesting as well as benefit from the technology by becoming familiar with it.

- I I use technology to facilitate whole language and student-centered classrooms and helps assess different learning styles.

- $\quad$ I use technology as much as possible in order to have students comfortable with and knowledgeable about this vital component of their present and future.

- $\quad$ Technology in the classroom allows my students to broaden their ideas and thoughts. Technology is a big part of my classroom.

One respondent noted that prior to the workshop; I could not write instructional or performance objectives according to Bloom's Taxonomy. Another stated, "I can now develop a rubric, which clearly spells out expectations for a culminating project, the different levels of performance, and the criteria for assessing the product at each level." I think about everything that I ask students to do. If it doesn't relate to standards, then I am leaving them out. I feel better about requiring them to do things with technology because I feel better about my ability to do it myself and show them how.

An important unintended consequence that has resulted from the project is the networks developed among the participants. As one participant put it:

A major benefit from participating in the workshop was the opportunity to become part of new networks: I am now part of a network of people who are interested in multimedia technologies. Had I not been part of the TIP workshops, I probably wouldn't be a part of that (network). Another major benefit was forming interdisciplinary collaborative groups. Before the workshop, we really didn't have much contact with the people in Education. Now, we (primary 
school teacher from one of the schools) are planning to form a technology users group so that we can better teach our ESL students.

\section{Other Lessons Learned}

While financial rewards motivated teachers to participate actively in technology-related professional development programs, their interest in gaining useful skills was most important. A high level of intrinsic motivation is required, as well as a desire to be proactive in strengthening ones courses and teaching. Therefore, any extrinsic rewards must be relevant to the work performed, and concerted efforts should be made to reinforce and nurture participants' intrinsic motivations. Because of their varied levels of interest and competence, tremendous preparation and time are required in order to assist teachers in developing advanced technology integration skills. Maximum effort is required in designing staff development for diverse ability groups and diverse learning styles. It is beneficial to preassess participants before workshops so that they can be assigned to comparable peer groups. One participant commented, "Sometimes when groups got together and helped each other, we were able to really learn a lot." Another pointed out, "I was overwhelmed by the number of assignments...because I work at a much slower pace than most of my peers." Yet, another participant said, "I need structure because I am not very disciplined." These and other lessons support those from similar efforts (Ireh \& Bell, 2002, 2004) used to train teacher education faculty at the university level. Specific lessons learned include:

- $\quad$ Get input from stakeholders (teachers in t his case);

- $\quad$ Group teachers by grade level or subject;

- $\quad$ Provide time for hands-on activities;

- $\quad$ Focus content on curriculum instead of software;

- $\quad$ Model classroom examples;

- $\quad$ Be flexible and listening to teachers' needs;

- $\quad$ Create a technology enhanced lesson plan;

- $\quad$ Provide access to appropriate hardware and software;

- $\quad$ Provide evaluation or feedback.

- $\quad$ Cover one thing with depth and focus than to cover several things quickly;

- $\quad$ Provide individualized technical support;

- $\quad$ Networking share information with other professionals;

- $\quad$ Participants will have wide variety of needs and skill levels;

- $\quad$ Concentrate on one skill or activity for each training session;

- $\quad$ Provide guided practice and independent work time for applying new skills learned;

- $\quad$ Provide practical hands-on activities;

- $\quad$ Teachers need time to implement knowledge and skills gained in workshop settings, as well as to practice technological skills needed for teaching and learning in their various disciplines;

- $\quad$ Pairing participants with different levels of proficiency is a good strategy for building skills;

- $\quad$ Teachers have a wide range of abilities from beginner to advanced;

- $\quad$ Handouts are important for continued practice after the workshop;

- $\quad$ Participants enjoyed being teamed up with teachers from another school system to develop thematic unit and lesson plans that integrate technology;

- $\quad$ Participants want the training session to be presented at a level appropriate to their skills;

- Workshops involving using the Internet as an instructional resource and creating web pages require a great deal of preplanning, organization, structure, and one-on-one time with each participant to be effective;

- $\quad$ Awarding CEU's is a strong attraction for teachers;

- $\quad$ Provide time for collaboration, discussion, and reflection;

- $\quad$ Financial incentives and knowledge/skill acquisition were both very important to participants; and

- Staff development should have very specific outcomes ("products") that are tied to the appropriate context. 
Some concerns that emerged from the project evaluations were designing staff development for diverse ability groups and diverse learning styles, meeting the needs of the disabled in the design of multimedia material, and providing adequate equipment for participants so that they could continue to practice and use their new skills in their classrooms and outside the school.

\section{RECOMMENDATIONS}

Based on the experience gained from designing, implementing, and assessing the product-based faculty professional development model, the following recommendations are proffered to interested readers. Workshop designers and implementers should review all the materials to determine the merits of grouping participants by level of proficiency. Likewise, the timing (during the academic year or during the summer) and duration of the workshop should be based on preassessment feedback. To ensure the efficient coverage of certain topics in the appropriate timeframe, the mix of individual and group assignments should be carefully examined. It is strongly recommend that more attention be paid to different learning styles. For example, some participants in this project reported that they were more comfortable working alone rather than in a group, while others preferred study guides with examples or models. Still others preferred a much slower pace with more individual attention. One participant cited difficulty multitasking (e.g., listening to the instructor, taking notes, and following the demonstrations, all at the same time).

Would-be adopters of this model should vary the structure of the workshop so that some demonstrations are presented to mixed ability groups and other topics are offered to groups based on skill level. Also, more supervised practice time should be incorporated. Make certain that there is sufficient, properly working equipment (hardware and software) available for practice and that the hours for accessing the equipment are appropriate within the context of participants' schedules. More specifically,

- Clearly describe the expected outcome or product to the participants and include a performance rubric/checklist.

- $\quad$ Provide some tangible incentives.

- $\quad$ Provide the necessary tools, training and incentives to encourage the use and integration of technology into all teacher education courses.

- $\quad$ Get administrative endorsement of the model as the desirable approach for helping members of teachers develop technology integration skills.

- Develop assessment tools that tie outcomes to national and state standards and assessment processes.

- $\quad$ Put in place strategies for sustaining the results and the interests/motivations faculty members will develop.

\section{CONCLUSION}

Effective professional development is the crucial enabler in ensuring that teacher can effectively use and integrate technology in P-8 classrooms in ways that significantly improve the academic achievements of students. Through emphasis on job-embedded faculty professional development such as the product-based approach and backing it with incentives outside the traditional reward system, teachers have the opportunity to acquire as well as put into practice technology integration skills. They easily embraced the idea that all technology instruction must be about teaching with technology and not teaching about technology.

\section{REFERENCES}

1. Anderson, R. \& Becker, J. (2001). School investments in instructional technology. Teaching, Learning, and Computing Report, Report 8. Retrieved January 2, 2006, from http://www.crito.uci.edu/tlc/fi ndings/report 8/startpage.htm.

2. Bailey, G. D. \& Powell, D. (1998). Technology staff development and support programs: Applying Abraham Maslow's Hierarchy of Need. Leading \& Learning with Technology, 26(3), 47-51, 64.

3. Bielefeldt, T. (2000). Information technology in teacher education: A closer look. Atlanta, GA: Connecting at the Crossroads, National Education Computing Conference 2000 Proceedings. (ERIC Document Reproduction Services No. ED444451) 
4. Flowers, N., Mertens, S. B., \& Mulhall, P. F. (2002, May). Four important lessons about teacher professional development. Middle School Journal, 57-61.

5. Guskey, T. R. (2000). Evaluating professional development. Thousand Oaks, CA: Corwin Press.

6. Hirsh, S. (2000, Summer). Power of 1: Individual action can energize adult learning. Journal of Staff Development, 10-16.

7. Ireh, M. \& Bell, E. D. (2004). A Product Based Faculty Professional Development Model for Infusing Technology into Teacher Education, Contemporary Issues in Technology and Teacher Education, 3(3). Available at: http://www.citejournal.org/vol3/iss3/currentpractice/article1.cfm.

8. Ireh, M. \& Bell, E. D. (2002, July 27). Implementing faculty professional development: The product-based model. Paper presented at the PT3 Annual Grantees Meeting, Washington, DC. (Also available online at http://tip.wssu.edu/Tip/Dissemination/pt3-2002/product-model/paper/Product-Based.htm)

9. International Society for Technology in Education. (2000). National Educational Technology Standards for Teachers. Available at: $\underline{h t t p: / / c n e t s . i s t e . o r g / t e a c h e r s / t ~ s t a n d s . h t m l . ~}$

10. Kanaya, T., Light, D., \& Culp, K. M. (2005). Factors influencing outcomes from a technology-focused professional development program. Journal of Research on Technology in Education, 37(3), 313-329.

11. Loucks-Horsley, S., Hewson, P., Love, N., \& Stiles, K. (1997). Designing professional development for teachers of science and mathematics. Washington, DC: National Institute on Science Education.

12. Mandinach, E. \& Cline, H. (1992). The impact of technological curriculum innovation on teaching and learning activities. Paper presented at the Annual Conference of the American Educational Research Association, San Francisco, California. (ERIC Document Reproduction Service No. ED 345 717).

13. Marzano, R. J. (2003). What Works in Schools: Translating Research into Action. Alexandria, VA: ASCD.

14. Milken Exchange on Education Technology. (1998). Preparing our young people for a changing world: Policymakers, business leaders and public speak out on the role of education technology in America's classrooms. Santa Monica, CA: Milken Exchange on Education Technology.

15. National Center for Education Statistics. (2000). Teachers' tools for the 21st century: A report on teachers' use of technology. Retrieved November 25, 2002 from http://nces.ed.gov/pubsearch/pubsinfo.asp?pubid=2000102htm.

16. National Commission on Teaching and America's Future. (2003). No dream denied: A pledge to America's children. Washington, DC: Author.

17. National Council for Accreditation of Teacher Education. (2003). Summary data on teacher effectiveness, teacher quality, and teacher qualifications. Washington DC: Author.

18. National Staff Development Council (NSDC) (2001). NSDC standards for staff development, revised. Available: http://www.nsdc.org/standards/index.cfm.

19. Office of Technology Assessment. (2000). eLearning: Putting a world-class education at the fingertips of all children. Retrieved January 28, 2006, from http://www.ed.gov/Technology,elearning/e-learning.pdf.

20. Riel, M. \& Becker, H. (2000, April). The beliefs, practices, and computer use of teacher leaders. Paper presented at the meeting of American Educational Research Association, New Orleans, LA. Retrieved August, 2, 2004, from http://www.crito.uci.edu/tlc/findings/aera/startpage.html.

21. The CEO Forum on Education and Technology. (1999). School technology and readiness report. Professional development: A link to better learning. Washington, DC: Author. Retrieved July 9, 2003, from http://www.ceoforum.org/ downloads/99report.pdf.

22. U.S. Department of Education. (1999). Designing effective professional development: Lessons from the Eisenhower program. Washington, DC: U.S. Department of Education.

Acknowledgement: This project was made possible by NC Quest grant from the University of North Carolina's Center for Leadership Development through Title II of the US Department of Education. 
Appendix A: Project goal, objectives, outcomes, and assessment measures relating to technology integration.

\begin{tabular}{|c|c|c|}
\hline \multicolumn{3}{|c|}{ Goal: Significantly improve the technology integration skills of teachers in the partnership. } \\
\hline Objectives & Outcome(s) & Assessment Measure(s) \\
\hline $\begin{array}{l}\text { 1.1. Train participants to effectively } \\
\text { use and integrate a broad range of } \\
\text { appropriate technologies into } \\
\text { instruction to enhance students' } \\
\text { learning according to the International } \\
\text { Society for Technology in Education } \\
\text { (ISTE) standards for students and } \\
\text { teachers. }\end{array}$ & $\begin{array}{l}\text { Lesson plans indicating technology } \\
\text { integration in line with ISTE/NCDPI } \\
\text { standards, WebQuests, multimedia } \\
\text { presentations, spreadsheets, effective use } \\
\text { of the internet in the classroom, use of } \\
\text { various computer hardware and } \\
\text { software, use of SASinSchool. }\end{array}$ & $\begin{array}{l}\text { Technology survey (pre and post), live } \\
\text { portfolio, videos, observation, interviews, } \\
\text { students' work, reflections, summative } \\
\text { evaluation, self-evaluation, interviews, } \\
\text { focus groups. }\end{array}$ \\
\hline $\begin{array}{l}\text { 1.2. Train participants to use } \\
\text { technology resources to engage in } \\
\text { ongoing professional development and } \\
\text { lifelong learning and to communicate } \\
\text { and collaborate with peers, parents, and } \\
\text { the larger community in order to } \\
\text { nurture student learning. }\end{array}$ & $\begin{array}{l}\text { Brochures, flyers, newsletters, } \\
\text { multimedia presentations. }\end{array}$ & $\begin{array}{l}\text { Technology survey (pre and post), live } \\
\text { portfolio, videos, observation, interviews, } \\
\text { students' work, reflections, summative } \\
\text { evaluation, interviews, focus groups. }\end{array}$ \\
\hline $\begin{array}{l}\text { 1.3. Train participants to apply current } \\
\text { research on teaching and learning with } \\
\text { technology when planning learning } \\
\text { environments and experiences for ESL } \\
\text { and economically disadvantaged } \\
\text { students. }\end{array}$ & $\begin{array}{l}\text { Problem-based projects, applications of } \\
\text { WebQuest, multimedia lessons, and } \\
\text { Web-based resources for ESL and } \\
\text { economically disadvantaged students. }\end{array}$ & $\begin{array}{l}\text { Group Projects, live portfolio, videos, } \\
\text { observation, interviews, students' work, } \\
\text { reflections, summative evaluation, } \\
\text { interviews, focus groups. }\end{array}$ \\
\hline $\begin{array}{l}\text { 1.4. Train participants to use } \\
\text { technology resources to collect and } \\
\text { analyze data, interpret results, and } \\
\text { communicate findings to improve } \\
\text { instructional practice and maximize } \\
\text { student learning. }\end{array}$ & $\begin{array}{l}\text { Assessment measures for use with ESL } \\
\text { students, effective assessment strategies } \\
\text { that focus on high level thinking and } \\
\text { reasoning skills for ESL and } \\
\text { economically disadvantaged students, } \\
\text { alignment of assessment strategies with } \\
\text { ISTE-NETS for students and teachers } \\
\text { and NC Standard Course Study (K-6); } \\
\text { synthesis of the standards, improved } \\
\text { students' EOG test scores for ESL and } \\
\text { economically disadvantaged students. }\end{array}$ & $\begin{array}{l}\text { Internet/e-mail, live portfolios, poster } \\
\text { sessions. }\end{array}$ \\
\hline $\begin{array}{l}\text { 1.5. Train participants to apply } \\
\text { technology resources to enable and } \\
\text { empower learners with diverse } \\
\text { backgrounds, characteristics, and } \\
\text { abilities and to support learner-centered } \\
\text { strategies that address the diverse needs } \\
\text { of ESL students. }\end{array}$ & $\begin{array}{l}\text { Effective use of WebQuests, Concept } \\
\text { Mapping, use of software/CD Rom } \\
\text { technology. }\end{array}$ & $\begin{array}{l}\text { Live portfolios, poster sessions, } \\
\text { evaluation of students' EOG test scores } \\
\text { (computer skills), and Summative } \\
\text { evaluation. }\end{array}$ \\
\hline
\end{tabular}

\section{Appendix B: Technology Integration Survey}

This survey takes only about 20 minutes. Its purpose is to gather feedback from you regarding use and integration of technology in P-8 classrooms. Your participation is entirely voluntary and your responses will in no way be used such that you or anyone can identify who you are. All data collected will be treated as group data. 
PART I: Directions: On a scale of $1-5$ (with 1 being the least), rate (by circling) your ability to use ate the following technology equipment in ways that improve the academic performances of your students.

\begin{tabular}{|c|c|c|c|c|c|}
\hline \multirow[t]{2}{*}{ Technology Equipment } & \multicolumn{2}{|c|}{ Least } & $\stackrel{\longleftrightarrow}{\longleftrightarrow}$ & \multicolumn{2}{|c|}{ Highest } \\
\hline & 1 & 2 & 3 & 4 & 5 \\
\hline LCD Projector & 1 & 2 & 3 & 4 & 5 \\
\hline Computer (Desktop or Laptop - Windows platform) & 1 & 2 & 3 & 4 & 5 \\
\hline Computer (Desktop or Laptop - Mac platform) & 1 & 2 & 3 & 4 & 5 \\
\hline Calculator(s) & 1 & 2 & 3 & 4 & 5 \\
\hline Scanner(s) & 1 & 2 & 3 & 4 & 5 \\
\hline Digital Camera & 1 & 2 & 3 & 4 & 5 \\
\hline Video Camera (Digital or Analog) & 1 & 2 & 3 & 4 & 5 \\
\hline PDA (Personal Digital Assistant) & 1 & 2 & 3 & 4 & 5 \\
\hline Networked Drives, Devices, Servers, etc & 1 & 2 & 3 & 4 & 5 \\
\hline DVD/CD-R/RW, USB Drives & 1 & 2 & 3 & 4 & 5 \\
\hline Smart Board & 1 & 2 & 3 & 4 & 5 \\
\hline USB Memory Jump Drive & 1 & 2 & 3 & 4 & 5 \\
\hline
\end{tabular}

PART II: Directions: On a scale of $1-5$ (with 1 being the least and 5 the most), rate (by circling) your ability to perform the following instructional technology skills in ways that improved the academic performances of your students.

\begin{tabular}{|c|c|c|c|c|c|}
\hline Instructional Technology Skill & Lea & & & & \\
\hline Word processing to create written documents & 1 & 2 & 3 & 4 & 5 \\
\hline Word processing to create news letters, mail merge, templates, flyers, etc & 1 & 2 & 3 & 4 & 5 \\
\hline Desktop publishing software to produce newsletters or other specially formatted documents & 1 & 2 & 3 & 4 & 5 \\
\hline Spreadsheet software to organize, analyze, and report school-related numeric data & 1 & 2 & 3 & 4 & 5 \\
\hline Database software to organize and analyze data & 1 & 2 & 3 & 4 & 5 \\
\hline Presentations software to create and deliver lessons and for student reports & 1 & 2 & 3 & 4 & 5 \\
\hline Drill and practice software to build students' skills & 1 & 2 & 3 & 4 & 5 \\
\hline $\begin{array}{l}\text { Simulation software, modeling software, and interactive instructional software to enhance } \\
\text { student learning and analysis of curriculum-related problem situations }\end{array}$ & 1 & 2 & 3 & 4 & 5 \\
\hline Graphic tools and software to acquire, edit, and incorporate images into documents & 1 & 2 & 3 & 4 & 5 \\
\hline Online instructional tools and simulations to provide curriculum-related learning experiences & 1 & 2 & 3 & 4 & 5 \\
\hline Locating appropriate Internet resources for teachers and students & 1 & 2 & 3 & 4 & 5 \\
\hline Ability to use the Internet and navigate through pre-organized links & 1 & 2 & 3 & 4 & 5 \\
\hline Use of search strategies to locate useful curricular/instructional resources on the Internet & 1 & 2 & 3 & 4 & 5 \\
\hline $\begin{array}{l}\text { Web site (designed with software such FrontPage, Dreamweaver, etc) to support instruction } \\
\text { and communication with students }\end{array}$ & 1 & 2 & 3 & 4 & 5 \\
\hline Charts and graphs for enhancing understanding of information or data being presented & 1 & 2 & 3 & 4 & 5 \\
\hline $\begin{array}{l}\text { Knowledge of and adherence to school or district policies, copyright laws, safety, health, and } \\
\text { ethical standards with regard to technology use }\end{array}$ & 1 & 2 & 3 & 4 & 5 \\
\hline Select appropriate technology resources for classroom use & 1 & 2 & 3 & 4 & 5 \\
\hline Evaluate the suitability of software and hardware for instructional purposes & 1 & 2 & 3 & 4 & 5 \\
\hline Facilitate regular student use of computer technology & 1 & 2 & 3 & 4 & 5 \\
\hline Use technology to enhance assessment of students' performances & 1 & 2 & 3 & 4 & 5 \\
\hline Use technology to present instruction & 1 & 2 & 3 & 4 & 5 \\
\hline Conduct learning activities using computer technology & 1 & 2 & 3 & 4 & 5 \\
\hline Integrate technology-based learning experiences into instruction & 1 & 2 & 3 & 4 & 5 \\
\hline Use computer technology for problem-solving and critical thinking & 1 & 2 & 3 & 4 & 5 \\
\hline Use technology to facilitate individualized or cooperative learning experiences & 1 & 2 & 3 & 4 & 5 \\
\hline Create developmentally-appropriate Web Quest activities & 1 & 2 & 3 & 4 & 5 \\
\hline Concept mapping using Inspiration or Kidspiration software & 1 & 2 & 3 & 4 & 5 \\
\hline Streaming media for use in the classroom & 1 & 2 & 3 & 4 & 5 \\
\hline Use computer technology to maintain and analyze student performance & 1 & 2 & 3 & 4 & 5 \\
\hline
\end{tabular}

